Original Research Paper

\title{
Transposisi Didaktis dalam Mengatasi Kecemasan Matematis Siswa (Didactic Transpotion In Overcoming Students' Mathematical Anxiety)
}

\author{
Nofriana Mori Uma1, Dr. Ahmad Muzaki², Samuel Rex M. Making ${ }^{3}$ \\ 1,2,3 Program Studi Pendidikan Matematika, Sekolah Tinggi Keguruan dan Ilmu Pendidikan Weetebula, Indonesia
}

\begin{abstract}
Article history
Received: 19 August 2021

Revised: 14 October 2021

Accepted: 14 October 2021
\end{abstract}

*Corresponding Author: Nofriana Mori Uma, STKIP Weetebula, Tambolaka, Indonesia;

Email:novrianimoriuma@gmail.com

\begin{abstract}
Abstrak: Tujuan penelitian ini, untuk mendeskripsikan bentuk pemanfaatan transposisi didaktis sebagai sarana belajar siswa pada pembelajaran matematika. Jenis penelitian ini menggunakan penelitian studi literatur. Artinya, penelitian yang dilakukan oleh peneliti dengan mengumpulkan sejumlah jurnal dan skripsi yang berkenaan dengan masalah dan tujuan penelitian, dengan pendekatan kepustakaan.

Sumber data penelitian yaitu jurnal dan skripsi yang terkait dengan konsep yang diteliti, teknik analisis data menggunakan teknik analisis atau content analisis dilakukan proses memilih, membandingkan, menggabungkan dan memilah berbagai pengertian hingga ditemukan yang relevan.

Berdasarkan hasil penelitian studi literatur dari ke lima belas jurnal dan skripsi yang relevan dengan judul, menyatakan bahwa pemanfaatan transposisi didaktis sebagai sarana belajar siswa pada masa pembelajaran berhasil digunakan dalam pembelajaran matematika, karena dengan menggunakan transposisi didaktis dapat mengurangi kecemasan siswa dalam pembelajaran matematika sehingga siswa lebih banyak aktif dan cepat memahami apa yang disampaikan oleh guru.
\end{abstract}

Kata kunci: Pemanfaatan Transposisi Didaktis.

\begin{abstract}
The purpose of this study is to describe the form of using didactic transposition as a means of student learning in learning mathematics. This type of research uses literature study research.

This means that research conducted by researchers by collecting a number of journal and theses relating to the problem and research objectives with a literature approach. Sources of research data are journal and theses related to the concepts studied, data analysis techniques using content analysis techniques or content analysis are carried out by sorting, comparing, combining and sorting various meanings until relevant ones are found. Based on the results of research studies of literature from the fifteen journals and theses relevant to the title, it is was stated that the use of didactic transposition as a means of student lerning during the learning period is was succwssfully used in learning mathematics, because using didactic transposition could reduce student anxiety in learning mathematics so that student were more many are active and quickly understand what is conveyed by the teacher
\end{abstract}

Keywords: Utilization of Didactic Transposition

\section{Pendahuluan}

Kecemasan matematika merupakan salah satu hambatan yang sangat serius dalam pendidikan, serta berkembang pada anak-anak dan remaja ketika mereka dalam lingkungan sekolah Warren Jr, dkk (2005). Luo, Wang, dan Luo (2019) berpendapat bahwa kecemasan matematika merupakan sejenis penyakit. Secara khusus, kecemasan matematika mengacu pada reaksi suasana hati yang tidak sehat, yang terjadi ketika 
seseorang menghadapi persoalan matematika. Adapun permasalahan yang terjadi dimana mata pelajaran matematika hanya menjadi pelajaran hafalan bagi siswa, guru pun cenderung hanya mengejar target kurikulum yang ditentukan. Akibatnya pencapaian yang ingin dicapai bukan penguasaan murid tetapi bagaimana materi tersebut selesai untuk diajarkan. Selain itu juga kesalahan yang dilakukan siswa dapat menimbulkan hukuman sehingga siswa merasa cemas dalam menghadapi mata pelajaran matematika.

Hannula (2014) menyatakan bahwa kecemasan (anxety) merupakan keadaan emosi yang tidak menyenangkan atau adanya rasa ketakutan. Kecemasan adalah salah satu alasan mengapa hubungan interpersonal yang penting dalam memahami matematika. Hal tersebut karena kecemasan tersebut dapat meningkat, bersifat subjektif pada setiap individu, dan mempengaruhi sulit atau tidaknya pemahaman. kecemasan matematika mengacu pada reaksi suasana hati yang tidak sehat, yang terjadi ketika seseorang menghadapi persoalan matematika. Adapun permasalahan yang terjadi dimana mata pelajaran matematika hanya menjadi pelajaran hafalan bagi siswa, guru pun cenderung hanya mengejar target kurikulum yang ditentukan. Akibatnya pencapaian yang ingin dicapai bukan penguasaan murid tetapi bagaimana materi tersebut selesai untuk diajarkan. Selain itu juga kesalahan yang dilakukan siswa dapat menimbulkan hukuman sehingga siswa merasa cemas dalam menghadapi mata pelajaran matematika.

Menurut Chevallartd (1992) menyatakan bahwa untuk mengatasi kecemasan matematis siswa akan diterapkan pembelajaran dan belajar dimana pengetahuan yang ada akan dipelajari dan diajarkan ke suatu lembaga pendidikan. Hal berarti semakin tinggi kecemasan siswa, semakin rendah prestasi belajar matematika, begitu pula sebaliknya. Oleh karena itu, penelitian ini dilakukan untuk melihat apakah siswa masih cemas kendati telah ada cara penyampaian pelajaran yang menarik termasuk dalam mata pelajaran matematika.

\section{Metode}

Jenis penelitian yang digunakan adalah studi literatur. Studi literatur adalah cara yang dipakai untuk menghimpun data atau sumber-sumber yang berhubungan dengan topik yang diangkat dalam suatu penulisan. Menurut Morzali (2017:27), kajian literatur adalah suatu pencarian kepustakaan dengan cara membaca berbagai sumber buku, jurnal, dan terbitan-terbitan lain yang berhubungan dengan topik penulisan, sehingga menciptakan suatu karya tulis.

Dari penjelasan di atas maka dapat diartikan kajian literatur adalah sebuah penulisan yang berasal dari penelusuran sumber penelitian studi literatur atau kepustakaan yang merupakan serangkaian penelitian yang berkenaan dengan metode pengumpulan data pustaka, atau penelitian yang objek penelitian digali melalui beragam informasi kepustakaan (buku, jurnal ilmiah, koran, internet dan dokumen lainnya).

\section{Hasil dan Pembahasan}

\section{A. Hasil}

\section{Artikel 1 : Hasil penelitian yang dilakukan oleh Novita Eka Indiyani, dkk (2006) Efektivitas metode pembelajaran gotong royong (cooperative learning) untuk menurunkan kecemasan siswa dalam menghadapi pelajaran matematika}

Menurut Indiyani, dkk berdasarkan hasil penelitian yang telah diperoleh, maka dapat disimpulkan bahwa ada pengaruh pemberian perlakuan berupa Metode Pembelajaran Gotong Royong (Cooperative Learning) terhadap kecemasan siswa dalam menghadapi pelajaran matematika. Ada perbedaan kecemasan siswa dalam menghadapi pelajaran matematika pada kelompok eksperimen dan kelompok kontrol. Kelompok eksperimen yang mendapat perlakuan mengalami penurunan skor kecemasan siswa dalam menghadapi pelajaran matematika, sedangkan kelompok kontrol tidak. Hasil tersebut menunjukkan bahwa hipotesis dalam penelitian ini dapat diterima. Dengan menggunakan metode Pembelajaran Gotong Royong (Cooperative Learning) dapat mengurangi kecemasan siswa SMP dalam belajar matematika.

Kelebihan dan kekurangan variasi kelompok cooperative learning 
a. Kelebihan kelompok berpasangan

1) Meningkatkan partisipasi

2) Cocok untuk tugas sederhana

3) Lebih banyak kesempatan untuk kontribusi masing-masing anggota kelompok

4) Interaksi lebih mudah

5) Lebih banyak ide muncul

6) Lebih mudah dan cepat membentuknya

7) Guru mudah memonitor

b. Kekurangan kelompok berpasangan

1) Banyak kelompok yang akan melapor dan dimonitor

2) Lebih sedikit ide yang muncul

3) Jika ada perselisihan, tidak ada penengah

4) Membutuhkan lebih banyak waktu

5) Siswa mudah melepaskan diri dari kelebihan dan tidak memperhatikan

6) Kurang kesempatan untuk individu

Jadi dapat disimpulkan bahwa dengan menggunakan metode cooperative learning, dapat mengurangi kecemasan siswa dalam belajar matematika.

\section{Artikel 2 : Hasil penelitian yang dilakukan oleh Ulfiani Rahman, dkk (2015) Pengaruh kecemasan dan kesulitan belajar matematika pada siswa $x$ MA Negeri 1 Watampone Kabupaten Bone.}

Menurut Rahman, dkk berdasarkan hasil analisis statistik inferensial kecemasan belajar dan kesulitan belajar pada pelajaran matematika ternyata memberi berpengaruh terhadap hasil belajar matematika siswa kelas X MA Negeri 1 Watampone Kabupaten Bone. Sumbangsih pengaruh variabel kecemasan belajar dan kesulitan belajar pada pelajaran matematika sebesar 28,3\% sedangkan selebihnya $71,7 \%$ dipengaruhi oleh variabel lain yang tidak dimasukkan dalam penelitian ini.

Faktor-faktor yang mempengaruhi kesulitan belajar matematika adalah sebagai berikut:

a. Faktor-faktor yang bersumber dari diri sendiri

Faktor yang bersumber dari diri sendiri juga disebut sebagai faktor intern. Sebab-sebab yang tergolong dalam faktor ini adalah sebagai berikut:

1) Tidak mempunyai tujuan belajar yang jelas

2) Kurang minta terhadap bahan pelajaran

3) Kesehatan yang sering terganggu

4) Kecakapan mengikuti pelajaran

5) Kebiasaan belajar

6) Kurangnya penguasaan bahasa

b. Faktor yang bersumber dari lingkungan sekolah

Kesulitan belajar tidak saja berasal dari diri anak akan tetapi juga dari sekolah tempat anak mendapatkan pendidikan formal.

c. Faktor-faktor yang bersumber dari keluarga

Faktor dari lingkungan yang paling dekat adalah keluarga, karena sebagian besar waktu anak adalah di rumah. Maka, keluarga sangat mempengaruhi kemajuan studi anaknya, bahkan dapat dikatakan menjadi faktor dominan untuk sukses disekolah.

d. Faktor yang bersumber dari masyarakat

Masyarakat pada umumnya tidak akan menghalangi kemajuan belajar pada anak-anaknya, bahkan sebaliknya mereka membutuhkan anak-anak yang berpendidikan untuk kemajuan lingkungan 
masyarakat. Semakin tinggi tingkat pendidikan setiap warga akan semakin tinggi tingkat kemajuan dan kesejahteraan masyarakatnya.

Jadi, dapat disimpulkan bahwa berdasarkan hasil belajar siswa SMP dalam pembelajaran matematika masih rendah.

\section{Artikel 3 : Hasil penelitian yang dilakukan oleh Wagetama. I. Disai , dkk (2017) Hubungan antara kecemasan matematika dan self-efficacy dengan hasil belajar matematika siswa SMA $X$ Kota Palangkar Raya}

Menurut Disai, dkk hasil penelitian juga ditemukan bahwa walaupun siswa merasa cemas dalam menghadapi ujian matematika, siswa tidak merasa bahwa itu merupakan perasaan yang dapat mengganggu kinerja mereka dalam menghadapi pelajaran Matematika atau ujian Matematika. Hal ini terjadi karena siswa dalam penelitian ini mempunyai self-efficacy yang tinggi dalam menghadapi pelajaran Matematika dilihat dari skor mean hipotetik dan mean empiric setiap dimensi, sehingga siswa merasa yakin mampu menyelesaikan persoalan Matematika. Pernyataan di atas didukung oleh analisis data tambahan yang menemukan bahwa terdapat hubungan signifikan negatif antara kecemasan Matematika dan self-efficacy. Semakin tinggi kecemasan Matematika maka semakin rendah self-efficacy siswa, begitu pula sebaliknya semakin tinggi self-efficacy siswa maka semakin rendah kecemasan Matematikanya.

Bandura (1997) mengatakan bahwa terdapat tiga dimensi penting dalam self-efficacy setiap individu. Adapun dimensi tersebut adalah:

a) Level

Dimensi ini berkaitan dengan tingkatan kesulitan tugas. Persepsi individu akan berbeda dalam memandang tingkat kesulitan dari suatu tugas. Individu yang memiliki self-efficacy tinggi akan cenderung memilih mengerjakan tugas-tugas yang sifatnya sulit dibandingkan dengan yang sifatnya mudah. Individu akan melakukan kegiatan yang dirasa mampu untuk dilaksanakan terutama kegiatan yang diperkirakan di luar batas kemampuan yang dimiliki. Semakin tinggi tingkat kesulitan tugas maka semakin tinggi pula tuntutan self-efficacy individu tersebut.

b) Generality

Dimensi generality menjelaskan tentang keyakinan individu untuk menyelesaikan tugas-tugas tertentu dengan tuntas dan baik. Hal ini berkaitan dengan bidang pencapaian individu seperti penguasaan tugas, penguasaan materi, serta mengatur waktu. Tidak semua individu mampu melakukan tugas dalam beberapa bidang tertentu akan tetapi individu yang memiliki self-efficacy yang tinggi cenderung menguasai tugas dari berbagai bidang berbeda. Sementara itu, individu yang memiliki self-efficacy rendah hanya menguasai tugas dari bidang-bidang tertentu saja.

c) Strength

Dimensi ini berkaitan erat dengan kekuatan akan keyakinan yang dimiliki oleh individu. Hal ini meliputi gigih dalam belajar, gigih dalam menyelesaikan tugas-tugas, serta konsistensi dalam mencapai tujuan. Individu yang memiliki keyakinan yang kuat akan dalam dirinya tentu akan berusaha untuk mencapai tujuan yang ingin dicapai. Namun bagi individu yang tidak memiliki keyakinan yang kuat, maka individu tersebut akan mudah menyerah untuk berusaha mencapai tujuan yang telah ditetapkannya. Dapat disimpulkan bahwa, dengan menggunakan metode pembelajaran self-efficacy dapat mengurangi kecemasan siswa.

Artikel 4: Hasil penelitian yang dilakukan oleh Annisa Juliyanti, dkk (2020) Pengaruh kecemasan matematis dan konsep diri terhadap hasil belajar matematika siswa

Menurut Juliayanti, dkk secara parsial hanya faktor kecemasan matematis yang memberikan pengaruh terhadap hasil belajar matematika siswa. Sedangkan berdasarkan uji analisis regresi berganda diperoleh nilai Hitung sebesar 3,758 dengan nilai signifikansinya 0,044 $<0,05$ sehingga terdapat pengaruh yang signifikan antara kecemasan matematis dan konsep diri secara simultan terhadap hasil belajar matematika siswa. Diperoleh nilai R2 sebesar 0,308, artinya 30,8\% perubahan pada hasil belajar 
matematika siswa secara simultan dengan kecemasan matematis dan konsep diri, sedangkan 69,2\% sisanya dijelaskan oleh berbagai macam variabel lain yang tidak dianalisis dalam penelitian ini. Kecemasan matematis dan konsep diri terhadap hasil belajar matematika siswa mempunyai dampak negatif dari ketidak sukaan siswa terhadap matematika yaitu timbulnya rasa cemas ketika belajar matematika, rasa cemas yang dialami siswa pada mata pelajaran matematika disebut juga sebagai kecemasan matematis. Jadi dapat disimpulkan bahwa terdapat pengaruh negatif antara kecemasan matematis terhadap hasil belajar matematika siswa, berarti untuk mendapatkan hasil belajar matematika yang tinggi, siswa harus menekan atau mengendalikan kecemasannya.

\section{Artikel 5 : Hasil penelitian yang dilakukan oleh Fajar Riski, dkk (2019) Pengaruh kecemasan matematika terhadap kemampuan pemecahan masalah siswa di SMA.}

Menurut Riski, dkk pada artikel ini, diketahui hasil penelitian bahwa 1) rata-rata keterampilan pemecahan masalah matematika siswa adalah siswa yang memiliki kecemasan rendah memiliki skor yang sama dengan siswa yang memiliki kecemasan sedang, dan siswa yang memiliki kecemasan sedang lebih baik daripada siswa yang memiliki kecemasan tinggi, dan siswa yang memiliki kecemasan rendah memiliki skor lebih baik daripada siswa yang memiliki kecemasan tinggi 2) ada hubungan negatif antara kecemasan dan keterampilan pemecahan masalah 3) semakin tinggi tingkat kecemasan, semakin rendah keterampilan pemecahan masalah. Jadi, dapat disimpulkan bahwa ada perbedaan keterampilan pemecahan masalah matematika berdasarkan tingkat kecemasan, ada hubungan antara kecemasan matematika dan keterampilan pemecahan masalah matematika dan ada pengaruh antara kecemasan matematika dan keterampilan pemecahan masalah.

\section{Artikel 6: Hasil penelitian yang dilakukan oleh Zuraidah, dkk (2020) Pengaruh kecemasan matematika dan prokrastinasi akademik siswa terhadap hasil belajar matematika siswa kelas VIII SMP Negeri 7 Balikpapan}

Menurut Zuraidah, dkk hasil penelitian menunjukkan kecemasan matematika berpengaruh terhadap hasil belajar matematika secara signifikan dengan nilai signifikansi $0,023<0,05$. Kemudian prokrastinasi akademik berpengaruh terhadap hasil belajar matematika secara signifikan dengan nilai signifikansi $0,012<0,05$.

Model pembelajaran Self-regulated learning (SRL) adalah suatu proses seseorang mengaktifkan kemampuan kognitifnya untuk mengolah informasi dan mengasah kemampuan untuk mengatur sistem belajar mereka secara mandiri untuk mencapai tujuan pembelajaran yang diharapkan (Zimmerman dan Martinez, 1990). Kesuksesan belajar dan mengajar dimulai dari Self-regulated Learning (SRL).

1. Kesuksesan belajar siswa

Kesuksesan atau keberhasilan dalam pembelajaran merupakan dambaan setiap siswa dan guru. Menurut Sunaman (2005) dalam pembelajaran self regulated learning (SRL) ada 3 unsur yang ada dalam proses pembelajaran. Untuk mengoptimalkan hasil belajar diperlukan antara lain:

1) Motivasi diri (self motivation)

Self regulated learning (SRL) menekankan pada penumbuhan motivasi diri siswa. Motivasi dapat diartikan sebagai daya penggerak yang ada dalam diri seseorang untuk melakukan aktivitas tertentu.

2) Kepercayaan diri (self efficacy)

Self efficacy yaitu percaya terhadap diri sendiri, yaitu sebagai keyakinan tentang kemampuan yang dimiliki untuk dapat menyelesaikan tugas yang diberikan.

3) Evaluasi diri (self evaluation)

Self evaluation, yaitu penelitian terhadap kinerja yang ditampilkan oleh diri sendiri dalam upaya mencapai tujuan dan menyebabkan yang signifikan terhadap hasil yang dicapainya. 
2. Kesuksesan mengajar bagi guru

SRL adalah sikap belajar mandiri siswa dalam pembelajaran, ternyata juga harus digunakan guru/pengajar dalam proses pengajarannya dalam memecahkan permasalahan mengajar yang bertujuan untuk mencapai kesuksesan dalam mengajar.

Jadi dapat disimpulkan bahwa, self regulated learning (SRL) tidak berpengaruh terhadap prestasi belajar pada tingkat kecemasan siswa SMP dalam menghadapi mata pelajaran matematika.

\section{Artikel 7 : Hasil penelitian yang dilakukan oleh Elvita Novia Dinawati, dkk (2020) Pengaruh kecemasan matematika terhadap berpikir kreatif siswa SMP}

Menurut Dinawati, dkk berdasarkan hasil analisis data dapat disimpulkan bahwa kecemasan matematika berpengaruh negatif terhadap berpikir kreatif dan memiliki korelasi negatif dengan tingkat korelasi yang sedang antar variabelnya. Hal ini dapat diartikan bahwa semakin tinggi tingkat kecemasan matematika maka semakin rendah berpikir kreatif siswa.

\section{Artikel 8 : Hasil penelitian yang dilakukan oleh Wuryaning Hendri Hastuti, dkk (2018) Pengaruh self-regulated learning, kecemasan matematika, dukungan sosial guru matematika, dan dukungan sosial teman sebaya terhadap prestasi belajar siswa SMP Negeri " $X$ " Surabaya}

Menurut Hastuti, dkk hasil penelitian menyimpulkan ada pengaruh self-regulated learning, kecemasan matematika, dukungan sosial guru matematika, dan dukungan sosial teman sebaya secara simultan terhadap prestasi belajar matematika sebesar $13.2 \%$

\section{Artikel 9 : Hasil penelitian yang dilakukan oleh Risma Nurul Auliya, dkk (2016) kecemasan matematika dan pemahaman matematis.}

Menurut Auliya, dkk Koefisien regresi X sebesar -0,565 menyatakan bahwa setiap ada penambahan satu nilai untuk kecemasan matematika akan menurunkan kemampuan pemahaman matematis sebesar 0,565 .

\section{Artikel 10 : Hasil penelitian yang dilakukan oleh Astri Widya Sari, dkk (2012) Tingkat kecemasan siswa dalam menghadapi ujian sekolah ditinjau dari jenis kelamin, jurusan dan daerah asal serta implikasi}

Menurut Sari, dkk artikel ini, 1) terdapat perbedaan dengan sig 0.000, dimana rata-rata skor siswa perempuan lebih tinggi (mean 164.4) dibandingkan siswa laki-laki (mean 152.2). 2) terdapat perbedaan dengan sig 0.005, dimana rerata skor siswa pada jurusan IPA lebih tinggi (mean 160.1) dibandingkan siswa pada jurusan IPS (mean 155.4). 3) terdapat perbedaan dengan sig 0.000, dimana rerata skor siswa yang berasal dari Minangkabau lebih tinggi (mean 160.6) dibandingkan siswa yang berasal dari non Minangkabau (mean 154). 4) tidak terdapat interaksi antara jenis kelamin, jurusan dan daerah asal dalam menjelaskan tingkat kecemasan siswa dalam menghadapi US.

\section{Artikel 11 : Hasil penelitian yang dilakukan oleh Maghfira Maharani, dkk (2018) Media pembelajaran matematika berbasis kartun untuk menurunkan kecemasan siswa}

Menurut Maharani, dkk Pada tingkat kecemasan siswa setelah penggunaan media pembelajaran menurun, yaitu pada kategori kecemasan tinggi menurun dari $41 \%$ menjadi $0 \%$, kategori kecemasan sedang mengalami penurunan dari $35 \%$ menjadi $24 \%$, kategori kecemasan rendah berubah dari $24 \%$ menjadi 76\%. Jadi dapat disimpulkan bahwa, media kartun dapat menurunkan tingkat kecemasan siswa. 
Media kartun adalah Media yang biasa ditempuh untuk mencapai tujuan. Adapun Kelebihan dan kekurangan media kartun adalah sebagai berikut:

1. Kelebihan media kartun

a.Kartun dapat menarik perhatian peserta didik sehingga materi yang diajarkan dapat tersampaikan dengan baik.

b. Kartun dijadikan abstraksi dalam pembelajaran sehingga peserta didik dapat memahami materi lebih baik karena imajinasi peserta didik terpancing saat melihat kartun.

c.Kartun dapat memberikan dampak positif pada peserta didik berupa ingatan tentang materi yang diajarkan.

d. Kartun dapat menghilangkan kejenuhan dalam belajar.

Dari pendapat beberapa para ahli di atas, dapat disimpulkan bahwa kelebihan media kartun memiliki kemampuan besar untuk menarik perhatian, pesan yang besar bisa disajikan secara ringkas, dan kesannya akan tahan lama untuk diingat. Selain itu, pendidik dapat menerapkan sesuai pada ranah yang dipilih yaitu pengetahuan atau keterampilan dengan memberi tugas akhir baik lisan maupun tulisan.

2. Kekurangan media kartun

a. Perlu adanya pengawasan lebih pada proses pembelajaran karena peserta didik hanya akan bermain dengan kartun saja tanpa memperhatikan materi pelajaran.

b. Pemilihan kartun yang sesuai dengan materi sangat menentukan keberhasilan proses pembelajaran.

c. Pendidik membutuhkan waktu lebih lama dalam mempersiapkan materi yang akan diberikan.

Maka dari uraian di atas, dapat disimpulkan bahwa kekurangan pada media ini adalah kartun biasanya hanya menangkap esensi pesan, menuangkannya dalam bentuk gambar yang sederhana, dan mempengaruhi sikap atau tingkahlaku.

\section{Artikel 12: Hasil penelitian yang dilakukan oleh Yayah Umayah (2019) Penerapan model discovery learning dalam mengatasi kecemasan matematika siswa SMP}

Menurut Umayah, hasil belajar siswa yaitu siswa hanya 76\% (24 siswa) siswa yang mencapai $\mathrm{KKM} \geq 70$ pada siklus I sedangkan pada siklus II mencapai KKM $\geq 70$ sudah tercapai yaitu 90\% (29 siswa). Pada kecemasan matematis siklus I terjadi kecemasan matematis rata-rata masih 71 berdasarkan hasil refleksi dan siklus II terjadi penurunan kecemasan matematis menjadi 65 , penurunan kecemasan matematis $8,5 \%$.

Kelebihan dan kekurangan variasi kelompok cooperative learning

1. Kelebihan kelompok berpasangan

1) Meningkatkan partisipasi

2) Cocok untuk tugas sederhana

3) Lebih banyak kesempatan untuk kontribusi masing-masing anggota kelompok

4) Interaksi lebih mudah

5) Lebih banyak ide muncul

6) Lebih mudah dan cepat membentuknya

7) Guru mudah memonitor

2. Kekurangan kelompok berpasangan

1) Banyak kelompok yang akan melapor dan dimonitor

2) Lebih sedikit ide yang muncul

3) Jika ada perselisihan, tidak ada penengah

4) Membutuhkan lebih banyak waktu

5) Siswa mudah melepaskan diri dari kelebihan dan tidak memperhatikan

6) Kurang kesempatan untuk individu 
Jadi dapat disimpulkan bahwa dengan menggunakan metode cooperative learning, dapat mengurangi kecemasan siswa dalam belajar matematika.

\section{Artikel 13: Hasil penelitian yang dilakukan oleh Ignes Febryliani (2021) Hubungan kecemasan matematika dan self-regulated learning terhadap motivasi siswa sekolah menengah atas dalam pembelajaran matematika pada kelas virtual}

Menurut Febryliani hipotesis ketiga, untuk nilai Hitung diperoleh sebesar 63,792 dan nilai sig. diperoleh sejumlah $0,000<0,05$ jadi ada ikatan positif antara kecemasan matematika dan self-reguated dengan motivasi siswa pada pembelajaran matematika, terdapat pengaruh kecemasan matematika dan self-reguated learning terhadap motivasi siswa sebesar $30 \%$.

\section{Artikel 14 : Hasil penelitian yang dilakukan oleh Mukhamad Ady Wahyudy, dkk (2019) Penerapan pendekatan concrete-pictorial-abstract (CPA) dalam menurunkan kecemasan matematika siswa sekolah dasar}

Menurut Wahyudy, dkk pada artikel ini, hasil analisis deskriptif dan perhitungan uji inferensial berupa uji perbedaan rata - rata untuk menganalisis hipotesis yang diajukan. Jenis penelitian yang digunakan adalah penelitian Research and Development (R\&D) dengan desain penelitian adalah kuasi eksperimen serta pretes dan postes kontrol grup desain dalam topik pembelajaran geometri yang melingkupi materi bangun ruang kubus dan balok. Hasil analisis deskriptif menunjukkan skor $N$-Gain siswa yang mendapatkan pembelajaran dengan pendekatan CPA lebih baik dari siswa yang mendapat pembelajaran konvensional. Hasil penelitian ini ditunjang oleh hasil analisis data inferensial yang menerima H0. Disimpulkan bahwa, penurunan kecemasan matematis siswa sekolah dasar yang mendapat pembelajaran dengan pendekatan Concrete-Pictorial-Abstract (CPA) lebih baik daripada siswa yang mendapat pembelajaran konvensional. Oleh karena itu, pembelajaran dengan pendekatan CPA dapat dijadikan sebagai bahan rujukan guru dalam menggunakan metode pembelajaran yang efektif, efisien, dan menyenangkan, terlebih pendekatan CPA dapat meningkatkan hasil belajar siswa dan dapat membuat siswa lebih percaya diri.

\section{Artikel 15 : Hasil penelitian yang dilakukan oleh Erma Pratiwi Nufi, dkk (2018) Konseling kelompok behavioural melalui teknik desensitisasi sistematik untuk mengatasi kecemasan siswa dalam menghadapi ujian akhir semester SMP Negeri 1 Watopute Kabupaten Muna}

Menurut Nufi, dkk Pada artikel ini, hasil analisis statistik inferensi dengan uji wilcoxon diperoleh Pvalue $=0,012$ selanjutnya dikonsultasikan dengan nilai $\alpha$ pada taraf signifikansi $5 \%$. Pvalue $<\alpha(0,012$ $<0,05) \mathrm{Hal}$ ini berarti H0 ditolak. Dapat disimpulkan bahwa hipotesis penelitian yang berbunyi layanan konseling kelompok behavioral melalui teknik desensitisasi sistematik dapat mengatasi perilaku kecemasan siswa kelas VIII dalam menghadapi ujian akhir semester di SMP Negeri 1 Watopute diterima.

\section{B. Pembahasan}

Berdasarkan uraian jurnal artikel dan skripsi di atas, maka penulis dapat mendeskripsikan kelebihan dan kelemahan serta menarik kesimpulan dari artikel jurnal dan skripsi yang relevan dengan judul penelitian peneliti

\section{Kelebihan.}

Kelebihan transposisi didaktif dalam belajar matematika dapat mengurangi kecemasan matematis siswa, dengan cara guru menggunakan berbagai metode pembelajaran yang berbeda, adapun metode tersebut yang digunakan oleh guru yaitu:
a. Transposisi didaktis
b. Cooperative learning
c. metode pembelajaran self-efficacy
d. Self Regulated Learning (SRL). 
e. Media kartun

Menurut Indiyani dkk, dengan menggunakan metode cooperative learning dapat mengurangi kecemasan siswa dalam pembelajaran matematika.

Adapun langkah-langkah cooperative learning, sebagai berikut:

a. Menyampaikan tujuan dan memotivasi siswa; guru menyampaikan semua tujuan pembelajaran yang ingin dicapai dan memotivasi siswa belajar.

b. Menyajikan informasi; guru menyajikan informasi pada siswa dengan jalan demonstrasi atau lewat bahan bacaan.

c. Mengorganisasikan siswa kedalam kelompok-kelompok belajar; guru menjelaskan pada siswa bagaimana caranya membentuk kelompok belajar dan membantu setiap kelompok agar melakukan transisi secara efisien

d. Membimbing bekerja dan belajar; guru membimbing kelompok belajar pada saat siswa mengerjakan tugas

e. Evaluasi; guru mengevaluasi hasil belajar tentang materi yang telah dipelajari atau masingmasing kelompok mempresentasikan hasil kerjanya

f. Memberikan penghargaan; guru mencari cara-cara untuk menghargai baik upaya maupun hasil belajar individu dan kelompok.

Dengan demikian dengan menggunakan metode atau model belajar tersebut, guru dapat mengatasi kecemasan matematis siswa sehingga dengan begitu siswa dapat memperoleh hasil belajar yang baik atau dapat meningkatkan prestasi belajar.

\section{Kelemahan}

Menurut Jemaris Martini (2014) juga mengemukakan bahwa kesulitan yang dialami oleh siswa adalah sebagai berikut:

1) Kelemahan dalam berhitung

2) Kesulitan dalam mentransfer pengetahuan

3) Pemahaman bahasa matematika yang kurang

4) Kesulitan dalam persepsi visual

Pendapat lain datang dari Wood (2007):

a. Kesulitan membedakan angka, simbol-simbol, serta bangun ruang.

b. Tidak sanggup mengingat dalil-dalil matematika

c. Menulis angka tidak terbaca atau dalam ukuran kecil

d. Tidak memahami simbol-simbol matematika

e. Lemahnya kemampuan berpikir abstrak

f. Lemahnya kemampuan metakognisi (lemahnya kemampuan mengidentifikasi serta memanfaatkan alogaritma dalam memecahkan soal-soal matematika)

Berdasarkan beberapa pendapat di atas, dapat disimpulkan bahwa kesulitan belajar matematis siswa yang dialami oleh siswa berbeda-beda yaitu dimulai dari kesulitan yang berkaitan dengan konsep, prinsip, kesulitan dalam penggunaan simbol, kesulitan karena lemahnya dalam berhitung, dan kesulitan dalam memahami bahasa matematika, misalnya siswa kurang memahami rumus-rumus matematika.

Berdasarkan hasil penelitian dan pembahasan yang telah dikaji, penulis menarik kesimpulan bahwa dengan penerapan metode transposisi didaktis dalam pembelajaran dapat mengurangi kecemasan siswa dalam belajar matematika. Dengan begitu siswa yang mengalami kelemahan dalam berhitung atau siswa yang memiliki pengetahuan renda dapat teratasi dengan cara guru menerapkan metode pembelajaran yang dapat meningkatkan kemampuan belajar anak, siswa yang awalnya tidak bisa berhitung, tidak bisa mengerjakan soal matematika, atau bersosialisasi dalam kelompok belajar. Dengan penerapan metode pembelajaran transposisi didaktis di dalam kelas ataupun dalam proses pembelajaran sehari-hari guru dapat mengatasi siswa yang mengalami pengetahuan renda atau siswa yang memiliki tingkat kecemasan matematis yang tinggi. 


\section{Kesimpulan dan Saran \\ 1. Kesimpulan}

Dari hasil penelitian dan pembahasan yang telah dikaji maka dapat disimpulkan bahwa yang dapat mengatasi kecemasan matematis siswa terdapat beberapa model dan pendekatan dengan langkah-langka pembelajaran serta persamaan yang dapat digunakan
a. metode pembelajaran gotong royong (cooperative learning)
b. self-efficacy dengan hasil belajar matematika
c. konsep diri terhadap hasil belajar matematika siswa
d. Pengaruh self-regulated learning Pengaruh self-regulated learning
e. Media pembelajaran matematika berbasis kartun
f. Penerapan model discovery learning
g. pendekatan concrete-pictorial-abstract (CPA)
h. Konseling kelompok behavioural melalui teknik desensitisasi sistematik

Dari beberapa model pembelajaran di atas dapat mengurangi kecemasan matematis siswa SMP.

Terkait dengan penelitian ini, tingkat kecemasan siswa SMP dalam menghadapi mata pelajaran matematika. Pengalaman selama saya PPL di SMPK Plus Kasimo, dimana saya sempat mendapatkan informasi dari hasil wawancara dengan beberapa siswa tentang kesan selama belajar matematika. Siswa menganggap matematika itu tidak mudah. Siswa sering mengeluh pusing susahnya mencerna materi matematika yang disampaikan. Berdasarkan hasil pengamatan peneliti, sebagian besar siswa tidak antusias dan menunjukkan partisipasi yang minim selama belajar matematika. Beberapa siswa selalu tidak mau ketika diminta untuk menuliskan jawaban di papan tulis atau menjawab pertanyaan dari guru. Ini disebabkan karena siswa takut salah ketika mengerjakan soal dan mereka akan diberikan sangsi berupa hukuman.

\section{Saran}

Berdasarkan hasil penelitian yang relevan maka penulis mengharapkan skripsi ini bermanfaat untuk kelangsungan pendidikan dengan bantuan model pembelajaran. dari berbagai model pembelajaran agar peneliti yang akan datang menjadikan referensi dan bagi guru dapat menjadi alternatif pembelajaran dalam mengatasi kecemasan siswa dalam menghadapi pembelajaran matematika.

\section{Daftar Pustaka}

Hannula, M.S. (2014). Affect in Mathematics Education. Ensyclopedi of Mathematics Educat. Springer

Chevallard Y (1992b) Pendekatan teoritis untuk kurikulum. J Matematika 13 (2/3): 2015-230. http://yves.chevallard.free.fr/ SPIP / SPIP /IMG / pdf / A_Theoretical_Approach_to_Curric ula.pdf. Diakses 25 Oktober 2012.

Anita Lie. 2002. Cooperative Learning. Jakarta: Gramedia Widiasarana Indonesia.

Feist,Jess, dan Gregory JF. 2013. Theories of personality. Ed.8. Singapore: McGraw-Hill.

Warren, Carl S., dkk. 2005. Accounting. 21 edition. Thomas South-Western. 